\title{
LIST OF TABLES AND MAPS
}

TABLES

1. Districts of the Province of Cajamarca, Ranked by the Concentration of Rural Population on Haciendas, r 940 / 25

2. Average Annual Population Growth Rates, Province of Cajamarca, I 876-1 $940 / 30$

3. Estimated Person-Land Ratios, Province of Cajamarca, 1876 and $1940 / 3^{2}$

4. Arrendires of the Haciendas Santa Ursula and Porcón / 37

5. Employment in the Peruvian Sugar and Rice Industries, I9 I 2-I940 / $4^{8}$

6. Rental Arrangements on Haciendas in the Province of Cajamarca, I920-1950 / 6o

7. Rental Rates for Grazing Rights on Haciendas, I900-1944 / 66

8. Labor Use on the Hacienda Combayo, Late i 920 / 80

9. Daily Wage Rates on the Hacienda Combayo, I917-1928 / 82

10. Peasant Indebtedness on the Hacienda Combayo, I 928 and $1929 / 83$

11. Return per Hectare and per Labor Day Worked in Peasant Production on the Hacienda Combayo, I917/113

12. Average Amount of Landholdings, Animal Holdings, and Rental Payments by Resident Peasantry on the Hacienda Combayo, r9 7 / 113

13. Levels and Composition of Annual Household Income on the Hacienda Combayo, I9I $7 / 1 / 4$

14. Average Daily Wages Paid to Agricultural Field Hands in the Sugar Industry, $1912-1928 / 118$

15. PERULAC Suppliers, Daily Milk Collection, and Capacity Utilization, I $949^{-1} 978 / 5^{2}$ 
16. Observations on Daily Agricultural Wages for Males, Province of Cajamarca, I942- I976 / I6o

17. Registered Land Sales on Selected Haciendas / 176

18. Purchases of Haciendas by Gonzalo Pajares / 182

19. Land Sales by Gonzalo Pajares to the Resident Peasantry on Three Haciendas / 184

20. Observations on Monthly Wages of Milkmaids on Provincial Dairy Farms, $194^{2-1} 976 / 190$

21. Distribution of Land Purchases by Size on Selected Haciendas / 194

22. Price per Hectare, Land Sales on Selected Haciendas / 195

23. Average Value of Land Purchase and Equivalency in Animal Stocks and Wage Labor on Selected Haciendas / 197

24. Distribution of Land Purchases on Selected Haciendas According to Registered Owner / 200

25. Estimated Average Annual Migration from the Department of Cajamarca to Selected Areas of Peru, 1952-198 I / 206

26. Characteristics of the Dairy Industry, Province of Cajamarca, 1972 / 214

27. Price of Milk Paid by PERULAC, I $944^{-1} 972 / 218$

28. Agricultural Enterprises Reporting to the Ministry of Labor, Department of Cajamarca, 1965-1981 / 222

29. Participation of the Peasantry in the Sale and Purchase of Labor Power, Province of Cajamarca, 1973 / 224

30. Cash Wages and the Payment of Labor in Kind, Province of Cajamarca, I 944 and $1976 / 227$

31. Agrarian Reform Adjudications, Province and Department of Cajamarca, December 3I, 1980 / 239

32. Associative Enterprises, Province of Cajamarca / $244^{-245}$

33. Daily Wages Earned by Full-Time and Part-Time Wage Workers, Province of Cajamarca, 1973 and 1976 / 259

34. The Class Analytics of the Composition of Peasant Household Income / 270

35. Rates of Participation in Income-Generating Activities, by Land-Size Strata, $1973 / 273$

36. Sources of Income: Composition of Net Income, by Relative Importance of Source and Land-Size Strata, Province of Cajamarca, I973 / 275

37. Household Participation in Multiple Class Relations, by Land-Size Strata, Province of Cajamarca, I 973 / 277

38. Levels of Household Reproduction, by Land-Size Strata, Province of Cajamarca, I 973 / 279

39. Productivity and Surplus Appropriation in Agricultural Production, Province of Cajamarca, 1973 / 28I

40. Frequency Distribution of Activities of Peasant Households, by Principal Family Member Responsible, Province of Cajamarca, I 976 / 283 
41. Composition of Household Income, Province of Cajamarca, 1917 and 1973 / 290

42. Life History of María Rumay de Aguilár of Pariamarca / 293

43. Life History of Rosa Fernández de Sangay of La Succha / 294

44. Principal Activity of Children Who Have Left Home, by Sex and LandSize Strata, Province of Cajamarca, $1976 / 308$

Al. Concentration of Population on Haciendas, Department of Cajamarca, 1876 and $1940 / 328$

A2. Concentration of Population on Haciendas, Province of Cajamarca, I 876 / 329

\section{MAPS}

1. Peru, Department of Cajamarca and Selected Departmental Capitals Highlighted / xii

2. Southern Provinces of Department of Cajamarca, Provincial Capitals, Province of Cajamarca and District Capitals Highlighted, i97os / 26

3. Province of Cajamarca, District Capitals and Selected Haciendas, I940s / 28 


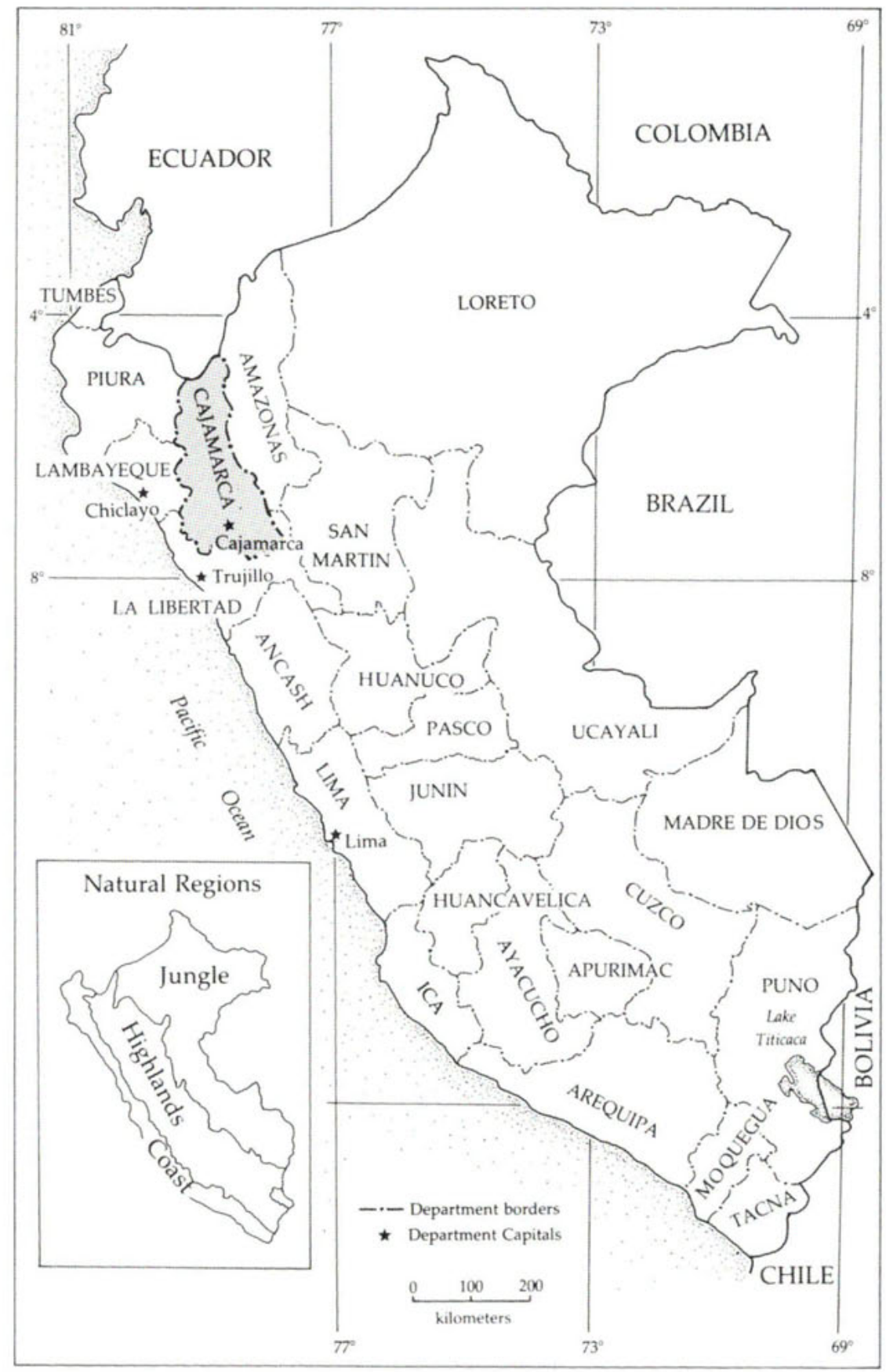

Map 1. Peru, Department of Cajamarca and Selected Departmental Capitals Highlighted 